\title{
Tradition and the culture of rights at the crossroads: A literary perspective
}

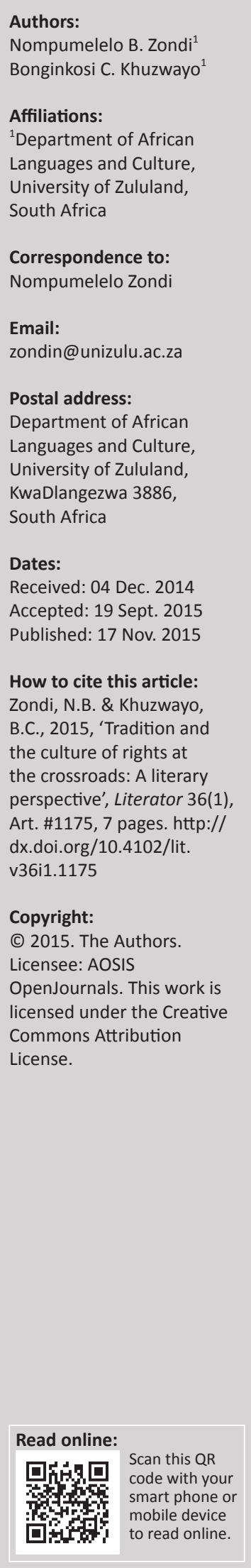

Using cultural theories, this article focuses on a literary text that presents a fresh perspective on one of the cultural practices of disposing of a dead body, namely cremation. The scarcity of burial sites is increasingly becoming a concern for municipalities, yet traditional ways of thinking are strongly against cremation. The liberty to investigate the burning issue of cremation as an alternative burial method in this way derives from the fact that through the ages literature (oral and written) has been effectively used by creative writers to offer an allusive quality and fictitious setting which has allowed them to comment on contemporary issues without blatantly seeming to do so. In this sense, the novel Intando kamufi ("Will of the deceased") by S. Mathaba contributes to various discourses on cremation, either reinforcing or critiquing it.

Tradisie en die kultuur van menseregte by die kruispad: 'n Literêre perspektief. Uit 'n kulturele oogpunt fokus hierdie artikel op 'n literêre teks wat 'n nuwe perspektief bied op 'n kulturele begrafnisgebruik, nl. kremasie. Die skaarste aan begraafplekke word al hoe meer 'n bekommernis van munisipaliteite. Die vryheid om die kwessie van lykverbranding as alternatiewe begrafnismetode op hierdie wyse te ondersoek, berus op die feit dat literatuur (mondeling en geskrewe) deur die eeue heen effektief deur kreatiewe skrywers gebruik is om kommentaar te lewer op eietydse kwessies, sonder om blatant propagandisties te wees. In hierdie sin lewer die roman Intando kamufi (Die oorledene se wil) deur S. Mathaba 'n bydrae tot die verskillende diskoerse wat kremasie óf ondersteun, óf veroordeel.

\section{Introduction}

Africa is going through a tremendous and rapid transformation in every aspect of human life; some of these changes are more circumstantial than others. People are becoming increasingly detached from the corpus of their tribal traditional beliefs and practices, especially in the context of cities where they mingle with diverse cultures. One of the adaptations pertains to cremation, the act of disposing of a deceased person's body by burning, an issue not restricted to KwaZulu-Natal as studies from elsewhere show (Jackson 1998; Nawa 2010). Zulu people, the main population group in the province of KwaZulu-Natal in South Africa and descendants of King Shaka Zulu, are known to resolutely hold onto their cultural beliefs, especially those that touch on the amadlozi, the ancestors. The current debate on cremation as an alternative burial system at a time when land for municipal burial sites is increasingly becoming a scarcity thus becomes valid and critical. A cultural expert, Msimang (1986:134), states that in a traditional African society, life is a person's greatest asset, and a gift from above, and as such its conservation and extension should be humankind's utmost concern. Traditional Zulu society perceived marriage as a vital component of the continuation of a man's lineage, so that he could reach the status of 'ancestor' and be valued and evoked by his progeny for a number of generations to come. A woman was 'brought in' as a kind of 'borrowing' to 'do the job' of creating children for the man and his clan; hence, the institution of ilobolo (bride price) and ukulobola, the process of obtaining a wife through the exchange of property.

In African cultures the custom of ukulobola is a practice related to gender construction. Within the established patriarchal system, this custom is sometimes a source of distress for women, because men tend to consider them 'paid for' or 'bought commodities' to be treated as they please. In the selected novel it will be demonstrated how the main character tries to extend his authority beyond acceptable boundaries with debilitating consequences, even for himself. In this process he verbally abuses the female protagonist, who represents women as one of the categories of oppressed persons (Lord \& Dufort 1996). He even tries to have her killed. The novel examined in this article is pertinent as it was published at a time when burial sites are becoming scarce, thus encouraging people to seriously consider alternative ways of disposing of the dead, such as cremation. Historically, cremation had no place in the Zulu tradition. 


\section{Synopsis of the text, Intando kamufi}

In order to appreciate what is being focused on in the following discussion, it is worth providing a brief contextual background of the novel.

Literally translated, the title of the Zulu novel Intando kamufi (Mathaba 2012) means "The will of the deceased". As the story begins, readers are made aware of a man who has passed away and whose death is central to the plot. The death of Mangena causes divisions in his family. His father, Mnguni, and his mother, MaShezi, find themselves in the middle of a conflict with MaDube, Mangena's wife and hence their daughter-in-law, with regard to the disposal of Mangena's remains. After his marriage to MaDube, Mangena had moved from his rural home of Phathane in the outskirts of Empangeni to live in one of the suburbs in Richards Bay. In his will Mangena had expressed a desire to be cremated when he died, a wish that causes conflict in his family. His family, who live in the rural areas and who are still steeped in tradition, are of the opinion that the departed should receive a dignified funeral in the rural graveyard reserved for deceased family members; he should be buried alongside their ancestors. On the other hand, his family who lives in the city, detached from the village life and all that it represents, are of the opinion that the will of the late Mangena should supersede anything that any person may wish or say. As soon as Mangena's wife telephonically informs her fatherin-law of her husband's wish to be cremated, Mnguni angrily departs to the city to meet with his son's wife with the ultimate intention to persuade her to change her mind, for cremation, according to Mangena's father, cannot be his son's wish.

Mnguni has never been to his son's home and his journey there is not without incident. A young man who is a bus conductor is very rude to him when he shouts at him for mistakenly heading towards his seat without first paying his bus fare. He is bitten by the dogs when he wrongly identifies a house as his son's home. The maid in the same house behaves uncouthly towards Mnguni after his nasty experience with the dogs when she asks him whether he did not see the words clearly written in all three official languages of the province of KwaZulu-Natal: 'AKUNGENWA LAPHA, GEEN TOEGANG, ENTER AT YOUR OWN RISK'. Lastly, he is almost knocked down by city boys on bicycles while still recovering from the dog attack. With the help of his grandson whom he meets while still looking for his son's house, he eventually arrives at his destination.

Once there, Mangena's wife does not receive her fatherin-law warmly. He makes matters worse by immediately starting to implore his daughter-in-law to go to the village for ukuzila (mourning the death) for her husband while the funeral arrangements are in progress. The tradition of $u k u z i l a$ is defined as 'show $[i n g]$ respect ... by avoidance' (Ngubane, cited in Magudu 2004). In most African societies, the cultural rites of mourning and cleansing are gendered, discriminatory and life-threatening for women (Daber 2003). Perhaps that is why MaDube tells her father-in-law that she and her husband had discussed the issue of mourning and that he had expressed the desire that his wife should not follow the tradition. According to this custom the bereaved woman is expected to wear a particular kind of garment and sit at a particular place in the ancestral hut from the time of the news of the loss right up to the day of the burial. During this time she also has to cover her entire body with a blanket and she is expected to maintain silence and to whisper if she really has to say something. The elders of the family become her spokespersons to those who come to comfort the bereaved family. Even after the funeral she is still expected to continue mourning for the period dictated by her family. To make this going against the tradition even worse Mangena's wife insists on cremation according to the will of the deceased.

Latha (2001) asserts that in all cultures women who protest against their own situation are given the cold shoulder. Magudu (2004) observes that traditional women sometimes also resist the forces of patriarchy. The entire novel revolves around this theme of cremation: what is the cultural impact of accepting or rejecting cremation when balanced against human rights as well as the challenges of the times?

\section{About the author}

The author's background is relevant for the interpretation of the events that take place in the novel. Siphamandla Mathaba was born on 03 February 1976 in the northern part of Zululand on the outskirts of Richards Bay under the KwaKhoza Traditional Authority. He did his primary and secondary schooling at Nseleni. From a very young age he was passionate about writing novels and his dream was realised in 2011 when his first novel, Izindunduma zosizi nezinyembezi ('Tons of sorrow and tears', Mathaba 2011) was published. The novel Intando kamufi, which is being examined in this article, is his second endeavour and it won third place in the KwaZulu-Natal Literature Competition, which qualified it for the final round of the MNET Awards in 2013. During an interview with us, Mathaba gave a pertinent answer to the question: Precisely, what informed the writing of Intando kamufi?". We find his lengthy response worth quoting verbatim here as it focuses on the cremation discourse, which is an overriding theme in the novel:

My purpose for writing this novel is mainly didactic in nature. You see, writers have a duty to comment on controversial issues without causing strife to anyone. Steeped as I am in culture, as a writer I felt I had to be the voice of reason in tough times which demanded extreme measures. (S. Mathaba, pers. comm., 04 September 2014; our English translation)

Perry Nodelman (1996:288) offers a useful explanation of what 'didactic text' means in this context: 'when the primary purpose of a book is to instruct or convey ideology, it is commonly referred to as didactic'.

When the author in uncompromising terms states that his novel is 'mainly didactic in nature', the question then is: what is his stance on cremation and which ideology is he trying 
to convey? We will return to the interview with him in the course of our argument.

\section{Context of the novel}

As authors, we do not, in any way, want to overthrow the family structure as it exists in most African societies where a man, umnumzane, is the head of the family as this is still applicable in contemporary times. It is the idea of retaining elements of tradition where there is no evidence that transgressing them has brought harm to anyone that this article is confining itself to. The position we take is informed by studies which show that some families have, without any pressure being placed on them, by choice, cremated their loved ones even at a time when burial land was not a problem (Zwane 2011). In those circumstances families were honouring the wishes of the deceased in the same way as the character, Mangena, in our selected novel wanted to be cremated. A few years have passed since the families in the abovementioned study cremated their loved ones and they have not met with catastrophic consequences. On the issue of cremation, the author said in the interview:

'I am a person who walks around with my ears and eyes wide open. I love listening to current issues making rounds in my country, province and in my community in particular. I read newspapers as a follow-up to those news or rumours and this helps me discern if what I have heard is worth pondering. One of the topics presently making news in local newspapers is cremation as another method of burying the dead given the frequent deaths that overwhelm KwaZulu-Natal in the light of the HIV and AIDS pandemic claiming more lives in this province than elsewhere in the country. Five years ago there was no week that went by without the topic of cremation making headlines in one newspaper or another within the eThekwini municipality. That municipality was running out of burial sites in Durban's townships and surrounding areas as a result of people flocking to the city which promised better employment opportunities. $\mathrm{Mr}$ Ngcobo, a Parks Department Municipal Manager, thought the severity of the problem called for attention by all stakeholders; hence, izimbizo meetings to address the situation [were held]. It was during these gatherings that the possibility of cremation was voiced'. (S. Mathaba, pers. comm., 04 September 2014; our English translation)

The novel is thus informed by real circumstances in the country which involves the scarcity of burial land. This article investigates how the issue of cremation is framed and acted out in the novel.

\section{Theoretical framework informing the article}

For the optimum appreciation of the events that take place in the novel, one should keep in mind that different cultures may perceive the same phenomenon differently because of their differing underlying cultural values (McGee \& Warms 2004; Schalkwyk 2002; Sedgewick 2008; Smith 2001). In other words, cultural background influences the way we give, receive or perceive information and this renders societies different in their perceptions of the world around them.
While it might make good sense for other societies to cremate the remains of their loved ones, Zulu people, for example, generally do not perceive cremation to be an acceptable alternative burial method. For this society the traditional way of digging a grave and burying the corpse is the only logical and acceptable method of burial. The rationale behind this practice is that Zulu culture includes a belief system that appreciates the existence of a creator, $u$ Mvelingangi, as well as ancestors, amadlozi. According to the Zulu people, ancestors are the mediators between people and God. Msimang (1991) states that Zulu people believe it is only through the invoking of the ancestors that they can appeal to the spirit world and that the process of becoming an ancestral spirit begins with burial. As cremation was absent in the lives of the Zulu people it thus becomes a problem when something that represents the legacy from the past, bequeathed to society by the ancestors, suddenly becomes a subject to discussion. The more so as the Zulu believe that failure to obey the ancestors may result in the ancestors turning their backs on the living, which would mean misfortune for the latter. According to Zulu culture, cremation would only bring a curse on the living, for how can ashes suddenly be regarded as ancestors?

\section{In the interview, the author had this to say on the issue:}

'The challenge of burial sites was not confined to Durban as other municipalities in KwaZulu-Natal including uMhlathuze, the municipality serving my community, were also faced with a similar problem. Learning from eThekwini municipality, uMhlathuze also followed suit and initiated talks around the same issue of disposing of the corpses in other ways other than a conventional burial method. The traditional leadership in my area did not want to hear anything contrary to conventional burial methods, the reasons put forward being that it would bring about an unimaginable wrath of the ancestors to the entire village. According to our traditional leaders, the ancestors would not pardon anyone who adopted those sacrilegious ways of disposing of the bodies of their loved ones; worse still their anger would extend to all community members even those who did not subscribe to cremation'. (S. Mathaba, pers. comm., 04 September 2014; our English translation)

In the context of this article, the dispute between the wife of the deceased and her father-in-law with regard to the disposal of their loved one presents another complication since the people in the centre of the conundrum belong to the same society and the same family. That is why the tension between modernity and tradition also becomes relevant in this discussion. We argue that having lived in the rural area all his life, Mnguni and his wife are still steeped in tradition. On the other hand, the deceased and his wife appear to perceive traditional burial ways as one of the cultural rituals that call for reconsideration in line with changing times.

\section{Discussion}

In determining our response to the reading of this fictional narrative we have taken into account the fact that writers of lengthy fictitious texts often use particular devices to give shape to their ideas and to give them structure or form. These tactics include, among other things, setting, character, 
protagonist, narrator and narrative technique. One also has to acknowledge a distinctive feature of the literary texts, viz. that that they never quite fit the critical grids that readers try to place over them and that they always mean more than we can grasp and explain (Murray 1999:47). In other words, in engaging with Mathaba's novel we have to come up with our own responses, rather than simple accept the text at face value.

The novel Intando kamufi was written in the second decade of the 21st century, two years before the 20th anniversary of South Africa's democracy. The novel assumes the framework of the Bill of Rights enshrined in the Constitution of the Republic of South Africa (1996), but also highlights one of the challenges of this historical period, namely the conflict between modernity and tradition brought into focus by burial site shortages. The two areas that serve as settings of the novel really exist today. Although Mathaba's story is fictional rather than documentary, he does subtly construct a sense of black people living in the context of the real KwaZulu-Natal province in rural, urban and semi-urban milieux. It is also in this province that cremation is a subject currently being debated.

While there are several characters in this novel, the main ones are Mnguni, father of the deceased Mangena, and MaDube, wife of the late Mangena. Mnguni is the epitome of male dominance and the subjugation of women while MaDube stands for the liberation of women. MaDube is the protagonist since she gives the narrative its primary energy. Her actions regulate the direction of the narrative amid an antagonistic force embodied in the character of Mnguni.

The word 'theme' is commonly used as an umbrella term for the key thoughts found in and put forward by a piece of creative writing. If certain individuals, places and ideas keep recurring in the text and if certain areas or experiences are featured, these are indicative of the writer's main ideas and therefore are referred to as the theme or themes of the book (Murray 1999:65). When our story commences MaDube, the wife of the late Mangena is on the phone with Mnguni, her father-in-law. The conversation is about the funeral arrangements for the deceased. The two divergent views of the main characters and their respective supporters represent what Lèvi-Strauss terms 'binaries' and Axel Olrik calls the 'law of contrast' where factions hold conflicting opinions on the same subject (in Canonici 1996:47). When such a situation exists there is no simple way to reach a compromise; one view overtakes the other. This state of affairs in this novel becomes evident for the first time in the telephone conversation between MaDube and her father-in-law, Mnguni. The main issue under discussion pertains to the burial of the late Mangena. His father instructs his daughter-in-law to bury him in the traditional way.

\section{Uncompromisingly, MaDube retorts:}

Mina njengonkosikazi kaMangena ngimile ngimile kulokhu engikushoyo. UMangena wazisholo yena esaphila wathi ufuna ukulothiswa uma eseshonile. Angeke ngigudluke entandweni yakhe. Ukuthi uMangena uzalwa nguwe baba lokho akusho ukuthi sekumele uguqule intando yakhe ngoba nakhu engasekho. (p. 1) [As Mangena's wife I stand firm by what I have said. Mangena stated it himself that he wants to be cremated when he dies. I will not swerve from his will. The fact that he is your son, father, does not mean that you have to change his will simple because he is no longer alive.] (All translations from the novel are our own.)

Without listening to his daughter-in-law's words, Mnguni retorts:

Uthi uyazizwa MaDube ukuthi uthini kimi? Senginganqunyelwa nguwe ukuthi kumele ngenzeni ngesidumbu somntanami? Uyini wena laph'ekhaya? Ungafike ubhungule uMangena uyohlala naye edolobheni bese ungitshela ukuthi uMangena wathi ufuna ukulothiswa uma eseshonile! Yini le ongitshela yona? Angeke ukubone lokho. Kungasa ngifile! Kowami umuzi kuzokwenzeka intando yami. Uzalwa yimi uMangena. (p. 1) [Do you hear what you are saying to me? Are you the one who can decide on my behalf what to do with my son's corpse? What are you in this family? First, you took my son away from us and went to leave with him in the city and now you are telling me that he said he wanted to be cremated when he dies! What is it that you are telling me? That is not going to happen. I swear! It is my will that will prevail in my house.]

The dialogue above conveys each party's claim to their beliefs. Subsequent dialogues show that both sides stand firm in their opinions and that nothing is going to sway them from their lines of thought; an amicable consensus or compromise cannot be reached.

While most of the events occur in the urban area, some of them are set in the rural village, supporting the idea of a clash of cultures. Canonici (1996:12) argues that bold imagery such as repetition fixes ideas. Thus, when MaDube says 'ngimile ngimile kulokhu engikushoyo', the words are not randomly used but carefully selected and charged with the power of her resolve. MaDube's resolve is accentuated by the use of a repetitive reflexive form '-zi' in 'wazisholo yena esaphila' (he said it himself whilat he was still alive) as opposed to 'washo...' (he said...). By using the emphatic and reflexive form, the author seems to be appealing to the readers' sense of compassion towards the widow whose intention is not to make her father-in-law's life unpleasant but who, in becoming the voice of her late husband, demonstrates that women can challenge a culture which can be regarded as a tool for affirming and maintaining male authority (Ramphele \& Boonzaier 1988).

Regrettably, Mnguni's egotistic interpretation of MaDube's statement leads to his downfall. First of all he confuses issues when he talks of MaDube being the cause of his son abandoning his rural village whereas it was Mangena himself who had found rural life no longer appealing, having lived there all his childhood. His father had wanted to give him a plot in the homestead, but Mangena did not want that, as the following extract shows:

UMnguni wayefuna ukuba uMangena akhe khona lapha egcekeni noma amkhiphe inxiwa eliseduzane khona ezohlale 
esemehlweni akhe. Wangakuzwa kahle lokho uMangena. Wadlubulundela waphuma ngenkani wama kwelithi yena usekhulile usefuna ukuzimela njengendoda. (p. 5) [Mnguni had wanted Mangena to build his home on the premises or just a little further away from them so that he (Mnguni) could always keep an eye on him. Mangena did not buy into the idea and he obstinately left, claiming that he was a man and as such wanted to stand on his own.]

Mnguni is blinded by his views on patriarchal authority. A statement such as 'it is my will that will prevail in my house' is powerless since it disregards the reality that Mangena was a man in his own right and that his house is not in the village but in the city, a place that Mnguni did not know until after his son's death. The author uses bold imagery to paint a picture of a stubborn and frustrated son who moved away from the control of his father. The word dlubulundela (obstinately left) evokes a vivid picture of an exasperated son who wanted to rid himself of his domineering father. The metaphorical use of this word presents what Axel Olrik, when dealing with epic laws of the folk narrative, terms 'the law of tableaux scenes' (Canonici 1996:50). According to this description there are some scenes in the narrative with dominant images that characterise major events, which seem like sculptured or painted situations. The picture created by the author in the choice of this word affords one the ability to visualise a son deliberately moving away from his father's dictatorial rule, an act that, in the father's mind, was unwise.

To Mnguni's astonishment not only did Mangena's will state that he should be cremated, but that the entire ceremony would take place in the city and not in the village as his father expected. Moreover, the deceased had categorically stated that his wife should not mourn him in the traditional way as the religion they had adopted was against that practice.

All this is mind-blowing to Mnguni who tries all he can to assert his parental authority over MaDube:

Lalela lapha MaDube ngikutshele, engathi kukhona ongakwazi kahle. Kuyazilwa kwaMnguni uma kuvele isifo. Uma kungazilwa kini kulungile kodwa lapha kwaMnguni uma umuntu efelwe yindoda inzilo uyishaya iphelele kusuka phansi kubhozo kuze kuyophuma ekhanda. Ngakho-ke uzokwenza intando yakwaMnguni. ... Wena walotsholwa laph'ekhaya ... inkolo lena ongitshela ngayo ayikho ngaphezu komndeni nangaphezu kwesiko. (p. 21) [You listen here, MaDube and let me give you a piece of my mind. Mourning happens when there is death in the Mnguni family. If you do not mourn in your family that is fine but here in the Mnguni family a woman mourns her husband by wearing mourning garments. Therefore you are going to do the will of the Mngunis. We paid ilobolo for you. The religion you are telling me about does not supersede the dictates of this family and its customs.]

When he sees that he is losing the battle Mnguni conspires with various people with the objective of getting control over his son's remains. These collusions are motivated by the questions preoccupying his mind:

Usengaze alothiswe ngempela umntanakhe? Uzobabhekelwa ngubani abantu bakuleli zwe lakwaMthethwa? Zona izinyanya zakubo kwaMnguni zizothini? Yena uMangena uzovukela kumuphi umndeni? Ngabe okhokho bakhe bazomemukela yini uma ezofika kubo engumlotha. (p. 90) [Why really cremate my son? How is he going to face the Mthethwa community? What will his ancestors say? Into which family will Mangena be admitted after the cremation? Will their forefathers welcome him in the form of ashes?]

From a traditional point of view these certainly are legitimate questions. However, the author, Mathaba, seems to be advancing a dynamic view of culture that makes room for change when necessary. This could mean an end to patriarchal domination in favour of mindsets that reflect democratic values, values that would entail revisiting the past and making sure that women's voices also count. The widow's victory is an indication that women should resist and challenge patriarchal domination, especially where culture is viewed as inert. These sentiments come out strongly in the following excerpt from the interview with the author:

As a young writer I was compelled to bring in another perspective of culture: that it is not static. I had to remind society that its dynamic nature calls for reviewing whenever necessary. That is why my stance in the novel sees the triumph of the widow in cremating the remains of her husband against her father-in-law's desire for a conventional burial for his son. (S. Mathaba, pers. comm., 04 September 2014; our English translation).

In our opinion, the author supports the culture of rights. At the memorial service, MaDube is dressed like a mourning widow, yet she still looks modern in her fashionable hat and sunglasses. Mangena wants to choose the way he is to be buried in opposition to the cultural tradition. The author sympathises with MaDube as she unwaveringly fulfils her husband's wishes. Since the central message in the novel is about the wishes of the departed, it is worthwhile to quote from Mangena's will, which was read by Xaba, Mangena's attorney, at Mangena's memorial service:

Mina Mangena Philasande Mnguni ngifuna ukulothiswa uma sengifile ... angifuni ukuba umkami uMaDube angizilele. ... Konke lokhu engikubhale lapha phansi angiphoqwanga muntu ngako kuyintando yami. (p. 39) [I, Mangena Philasande Mnguni, wish to be cremated when I am gone. ... I do not want my wife MaDube to mourn me (in a traditional manner). All that I have written I do on my own will, no one has forced me to do it. It is my will.]

After the memorial service and despite what the will stipulates, Mnguni makes several attempts to claim his son's corpse but they all fail. Instead, he finds himself facing the law. He goes to the tribal court to contest the cremation option. Even though the tribal court supports Mnguni, the elders nevertheless see the matter as beyond their jurisdiction. They suggest the magistrate court. Their words illustrate that they understand the human rights enshrined in the constitution of the country:

Lolu daba oze ngalo ... seludinga inkantolo kamantshi kube yiyo ephuma nesixazululo kule nkinga. ... Kwankosikazi kamufi akanawo amandla okujika into esuke ibhalwe phansi ... noma ngabe yindodana yakho lena eshonile kepha ngeke uphikisane nentando yayo. (p. 66) [The matter you are bringing before this 
court requires to be dealt with at the magistrate court which should resolve it. ... Even the wife of the deceased has no power to change anything that is written down ... even though it is your son that we are talking about but you cannot go against his will.]

Mnguni even contemplates hiring people to kill MaDube just so he can claim his son's corpse. He confides these thoughts to his sister:

Akukho okunye ukuhlakanipha okumele simkhombise khona ngaphandle kokuba simthengele abafana bamthele phansi. ( $p$. 67). [There is no other way we can show her (MaDube) that we are wiser than her except by hiring killers to deal with her.]

Mnguni delays his plan to kill MaDube and instead procures an affidavit to the effect that Mangena is his son. This he takes to the mortuary to claim his son's corpse. The mortuary worker tries to reason with Mnguni, but he will not relent. A fight over Mangena's corpse ensues which results in Mnguni being taken to jail. The following day he is released on bail. This is when he feels he has no option but to have MaDube killed. He pays someone to do the dirty job for him. The hired killer takes the money but then decides not to commit the murder. He resolves to go back to Mnguni's house to let him know he is a converted man and will not kill for money. However, Mnguni stabs the killer thinking he has come to kill him. He lands in prison again and this time no bail is given: 'Useyobonana nezinye izinsizwa ejele laseQalakabusha. Mhlawumbe neyakhe impilo iqale kabusha' [He is going to be with other prisoners. Perhaps even his life will begin anew] (p. 119). He remains behind bars.

\section{Conclusion}

The article has highlighted the clash between traditional practices that have stood the test of time and the culture of rights espoused by South Africa's democracy, particularly those that uphold equality, personal rights, women's rights and gender rights. At issue also is the contemporary challenge of a lack of burial sites in municipal areas. This has led to debates about cremation as an alternative burial system. In the novel Mnguni represents the opposition against cremation, a practice that still is widely shunned throughout African culture, especially among the Zulu people. Mnguni exemplifies the resistance of Zulu people to cremation as an alternative to their traditional burial practices. Mnguni is nearly destroyed by his efforts to bury his son. This fictional image of the opposition against cremation is, as recent studies show, still in line with people's strong preference for traditional burial practices (Zondi \& Zwane 2014). We contend that this state of affairs is perpetuated by the fact that people have little or no knowledge about other burial methods, particularly cremation. The victory of cremation over the conventional burial method and the triumph of the wife of the deceased in the novel analysed suggests that traditional belief systems can be adjusted without jeopardising social harmony.

What has emerged from the reading of Intando kamufi is that culture is dynamic and as such should be dealt with in a flexible manner. Had the novel ended with Mnguni winning the cremation battle, this would have meant that the author still upholds male authority over the promotion of human rights and women's rights in particular. The much-needed tolerance between tradition and new ways of understanding the world will only be reached when communities are open to innovations that do not kill their traditions. Earlier on in the discussion we mentioned studies of Zulu families who opted to cremate their loved ones, without, after a number of years, any negative consequences. However, cremation will only become a generally accepted option once people have been properly educated about its advantages and disadvantages. The victory of a widow over the father of the deceased also suggests that women could be more assertive in making their voices heard amid the silencing voices of men.

\section{Acknowledgements Competing interests}

The authors declare that they have no financial or personal relationships that may have inappropriately influenced them in writing this article.

\section{Authors' contributions}

N.B.Z. (University of Zululand) was the mentor of B.C.K. (University of Zululand) throughout the project. Besides his valuable contribution throughout the writing of this article (until his passing on in September this year) B.C.K. provided most of the translations found in this article. Equal credit is due to both authors.

\section{References}

Canonici, N.N., 1996, Zulu oral traditions, University of Natal Press, Durban.

Constitution of the Republic of South Africa, 1996, 'Documents', viewed n.d., from http://www.gov.za/

Daber, B., 2003, 'The gendered construction of mournng and cleasing rites of widowhood among the Zulu-speaking people of Ndwedwe community', Unpublished Master's dissertation, Dept. of Gender Studies, KwaZulu-Natal University, Durban.

Jackson, P., 1998, 'Cremation now a hot option', Globe and Mail, viewed n.d., from http:/ps57gates.info/cremation-from-the-standpoint-of-religion-and-sentiment. html

Latha, H., 2001, 'Feminisms in African context: Maria Bâ's so long a letter', Agenda 12 75-77. http://dx.doi.org/10.1080/10130950.2001.9675991

Lord, J. \& Dufort, F., 1996. 'Power and opression in mental health', Canadian Journal of Community Mental Health 15(2), 5-11.

Magudu, B., 2004, 'AmaHlubi women's experience and perceptions of ukuzila', Agenda 18(61), 140-148. http://dx.doi.org/10.1080/10130950.2004.9676058

Mathaba, S., 2011, Izindunduma zosizi nezinyembezi, Oxford University Press, Cape Town.

Mathaba, S., 2012, Intando kamufi, Oxford University Press, Cape Town.

McGee, R.J. \& Warms, R.L., 2004, Anthropological theory: An introductory history, McGraw Hill, Arizona.

Msimang, C.T., 1986, Izimbongi izolo nanamuhla, Bard Publishers, Pretoria. Msimang, C.T., 1991, Kusadliwa ngoludala, Shuter and Shooter, Pietermaritzburg.

Murray, S.A., 1999, Language, text and context, teaching manual, University of Natal, Durban.

Nawa, D., 2010, 'Shortage of burial sites - How about cremation?', The Times of Zambia, 03 April, viewed from http:/allafrica.com/stories/201004050178.html

Nodelman, P., 1996, The pleasures of children's literature, Longman, New York.

Ramphele, M. \& Boonzaier, E., 1988. 'The position of African women: Race and gender in South Africa', In E. Boonzaier \& J. Sharp (eds.), South African keywords: The uses and abuses of political concepts, pp. 153-166, David Philip, Cape Town. 
Schalkwyk, J., 2002, Culture, gender equality and development co-operation, Canadian International Development Agency, Durban.

Sedgewick, P., 2008, Cultural theory: The key concepts, Routledge, Oxford and London. Smith, P., 2001, Cultural theory: An introduction, Blackwell Publishers Ltd., New Haven.
Zondi, N.B. \& Zwane, M., 2014, 'Perceptions of cremation as an alternative burial system among the Zulu people living in KwaZulu-Natal', Indilinga African Journal of Indigenous Knowledge Systems 13(2), 300-310.

Zwane, M., 2011, 'Perceptions on cremation among the Zulu people', Unpublished Master's dissertation, Dept. of isiZulu Studies and Literature, University of KwaZulu-Natal, Durban. 